\title{
The Future of Sustaining Energy Using Virtual Power Plant: Challenges and Opportunities for More Efficiently Distributed Energy Resources in Indonesia
}

\author{
Moh Fadli \\ Faculty of Law \\ University of Brawijaya \\ Malang, East Java, Indonesia \\ mfadlifh@ub.ac.id
}

\author{
Diah Pawestri Maharani \\ Faculty of Law \\ University of Brawijaya \\ Malang, East Java, Indonesia \\ dp.maharani@ub.ac.id
}

\author{
Airin Liemanto \\ Faculty of Law \\ University of Brawijaya \\ Malang, East Java, Indonesia \\ airin.liem999@gmail
}

\begin{abstract}
Energy plays a vital role worldwide. In Indonesia, there are $\mathbf{4 0}$ million people living without electricity and this lack of electricity has hindered investment. Meanwhile, fossil energy sources are predicted to run out by 2015. This alarming condition encourages the researchers to find alternative renewable energy resources for sustainable energy. Virtual Power Plant (VPP) is a promising solution, especially in terms of storage and distribution of the energy. VPP collects energy from geothermal power, water, sun, wind, and so forth, operated by a single energy generator. The electricity produced is processed and distributed to several units. However, to date Indonesia has not utilised VPP as a device for more effective energy distribution although VPP has successfully been implemented in US A, Australia, Canada, and Japan. This article is aimed to analyse possible chances and challenges to effectively distribute energy resources by utilising the technology of VPP to realise the concept of sustainable energy in Indonesia. The research result reveals that there are several challenges encountered over the implementation of VPP regarding, namely: (a) the policy of energy management that is not technology-based; (b) unavailability of infrastructure supporting VPP; (c) participation of societies in electricity procurement; and (d) cyber security threat. In other side, Indonesia has a big opportunity to implement VPP, which are: (a) the change in electrical energy consumption; (b) increasing renewable energy need; (c) better environmental awareness; (d) more complex market; and (c) increasing interest of developed countries in VPP.
\end{abstract}

Keywords: virtual power plant, renewable energy, legal policy

\section{INTRODUCTION}

Energy resource is the backbone of every state to survive, mainly related to economy [1]. To date, there are about 40 million people in Indonesia who do not enjoy electricity and some investment is hampered due to lack of electricity [2].

As the gross domestic product has been increasing and been projected to increase from 2012-2025, energy sector plays an essential role in the development of economy and energy sufficiency as part of national security. Annually, the gross domestic product grows about $7.1 \%$ in average, leading to the growth of energy which also rises as much as 4.7\% per year from 1,079 millions in 2012 to 1,960 millions equal to oil barrel in 2025 [3].

Since the need for energy in Indonesia rises, energy management must receive enough attention especially in terms of its provision, utilisation, and sustainable distribution. For long term enviro-friendly energy management, energy resource plan and development in Indonesia have to be supported by technology policy and innovation.

Energy crisis in Indonesia has become the main issue that absorbs the attention of Indonesian government. The permit extension of Freeport to export concentrate followed by the negotiation of Masela block and Indonesia Deepwater Development (IDD) and the cancellation of Feed-in Tariff (FIT) price launch for solar energy within the period of 20 working days by the Minister of Energy and Mineral Resources (ESDM) in 2016, strongly indicate that focus and attention of the Indonesian government has shifted to oil, natural gas, and coal sectors [4]. On the contrary, fossil energy resource in Indonesia is predicted to run out in 2050 [5].

The government is aware that energy sector is at its critical level. In the growth of renewable energy, network infrastructure in Indonesia is left behind, stops developing and is limited. Interrupted energy distribution is due to the lack of network capability to respond the need, such as blackout that causes loss for companies and lack of electricity distribution in remote regions. One of the main factors concerning the issue is caused by the incapability of the government to focus on advanced development of technology [6].

The government needs to accommodate new technology to improve efficiency and sustainability of energy distribution. One of the technologies that is adopted by Indonesian government is Virtual Power Plant (VPP), a system that integrates several resources to distribute the 
whole dependable supply [7]. This system utilises a group of different types, namely dispatchable and nondispatchable, controllable or flexible load (CL or FL) distributed generation (DG) systems that are centralized controlled and it includes microCHPs, natural gas-fired reciprocating engines, small-scale wind power plants (WPP)s, photovoltaics (PVs), run-of-river hydroelectricity plants, small hydro, biomass, back-up gensets, and energy storage systems (ESS) [8].

This system has benefits such as the ability to deliver peak load electricity or load-following power generation on short notice. Such a VPP can replace a conventional power plant while providing higher efficiency and more flexibility. More flexibility allows the system to react better to fluctuations, but whose complexity requires complicated optimization, control, and secure communications [8].

VPP has been proven successful to be applied in USA, Australia, Canada, and Japan. Therefore, it is expected that the government adopt this technology as measure to improve the efficiency of energy resource distribution. However, the transformation from old technology to the new one into network system of national energy through VPP certainly brings both of its positive and negative impacts. This writing is aimed to discuss opportunities and challenges over the implementation of VPP in Indonesia to realise the development of sustainable energy.

\section{CONCEPT OF VIRTUAL POWER PLANT AND ITS DEVELOPMENT}

Virtual Power Plant (VPP) is smart grid technology utilised to collect all units of power plant to be operated into a single power generator that is capable of controlling and managing electrical currents back to several units of power generator as needed. Virtual Power Plant can function well with both fossil fuel and renewable energy resource. In short, VPP works by managing and coordinating electric currents coming from generator, controlling power needed, and restoring it [9].

Virtual Power Plant relies on software and smart grid. With smart grid, problems can be solved and the management can be improved to a better one. Moreover, through VPP, consumers can serve as producers for the development of economy. Oliver et al suggest the technology of smart grid enables policy making and people have succeeded to manage the policy of sustainable energy. Furthermore, s mart energy technology, network and policy, and evaluating smart grid that enables policy makers to respond to emerging trend in energy are the three main pillars in sustainable economic development commonly known as 'trilemma' [10]. The comparison between traditional grid and smart grid is presented in Table 1.

TABLE 1.

COMPARISON BETWEEN TRADITIONAL AND SMART GRID [6]

\begin{tabular}{|l|l|l|}
\hline Component & Traditional grid & \multicolumn{1}{c|}{ Smart Grid } \\
\hline $\begin{array}{l}\text { Energy } \\
\text { generation }\end{array}$ & $\begin{array}{l}\text { Fossil based fuels } \\
\text { - nuclear, } \\
\text { hydroelectric, }\end{array}$ & $\begin{array}{l}\text { Renewable energy } \\
\text { sources like wind, } \\
\text { solar, biomass, }\end{array}$ \\
\hline
\end{tabular}

\begin{tabular}{|l|l|l|}
\hline & $\begin{array}{l}\text { thermal, fuel } \\
\text { centralized energy } \\
\text { production }\end{array}$ & $\begin{array}{l}\text { geothermal } \\
\text { Distributed energy } \\
\text { production }\end{array}$ \\
\hline Technology & $\begin{array}{l}\text { Analog - } \\
\text { electromechanical } \\
\text { solid state } \\
\text { devices; weak and } \\
\text { unreliable; little } \\
\text { use of ICT }\end{array}$ & $\begin{array}{l}\text { Digital - micro- } \\
\text { processorbased; } \\
\text { strong and reliable; } \\
\text { extensive use of } \\
\text { ICT }\end{array}$ \\
\hline $\begin{array}{l}\text { Communicat } \\
\text { ion }\end{array}$ & $\begin{array}{l}\text { Unidirectional; bi- } \\
\text { directional }\end{array}$ & $\begin{array}{l}\text { Bi-directional; } \\
\text { global }\end{array}$ \\
\hline $\begin{array}{l}\text { Business } \\
\text { models }\end{array}$ & $\begin{array}{l}\text { Consumers; static } \\
\text { Prosumers; } \\
\text { dynamic }\end{array}$ \\
\hline Protection & $\begin{array}{l}\text { Limited; manual } \\
\text { restoration }\end{array}$ & $\begin{array}{l}\text { Adaptive; self } \\
\text { healing }\end{array}$ \\
\hline Data & Limited & Abundant \\
\hline
\end{tabular}

Technically, VPP consists of three main components: (1) distributed energy resources; (2) energy storage systems and information; (3) Communication technology (see Figure $1)$.

FIGURE 1.

MODEL OF SIMPLE VPP [11]

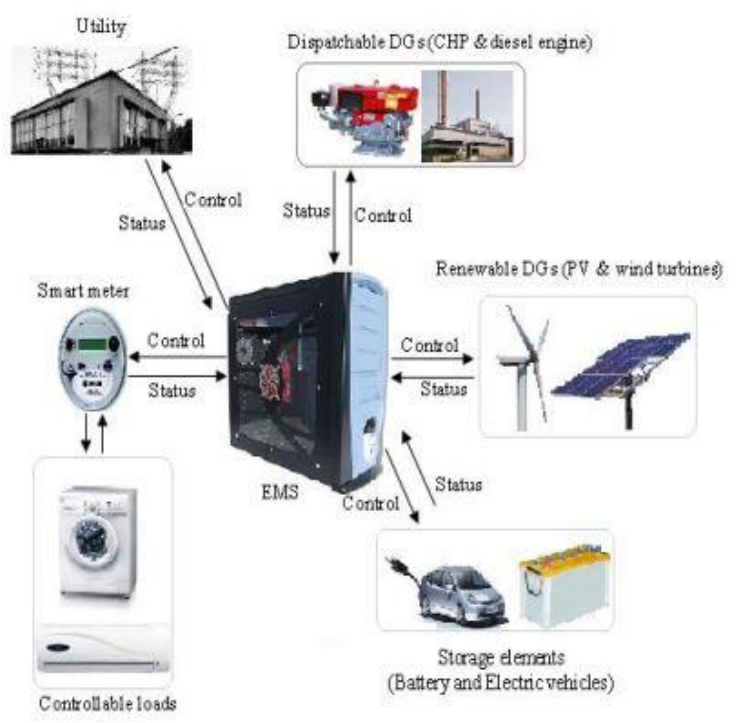

Operational system of VPP is addressed to trade, energy balancer, and system-of-interests-based network (SoI) [12]:

\section{VPP for trade}

This system has given access to energy trade to the owner of VPP. This system also optimises and collects capacity of energy distribution resource and provides energy in accordance to the market need. The owner of VPP can collectively propose to energy distributor for more optimal energy distribution.

2. VPP as energy balancer

This system is intended to function as energy balancer in short, middle and long term by utilising unit of available Distributed Energy Resources (DER), storage device, and controllable energy need. The 
duration needed for main control is provided in seconds, and VPP is contributing with fast response power obtained from spinning generator, capacitor, and fast batteries. Virtual Power Plant is also useful in additional control, e.g. the formation of spare unit of DER for several minutes and reducing demand to more controllable power load for several hours during unstable electrical power recovery.

\section{VPP for Network Services}

Increased electrical power means the need of extending the capacity of network or cutting excessive power load or setting solution in case of system failure. Virtual Power Plant could provide network services to TSO/DSOs to anticipate excessive power, minimise possibility of failure, and increase power quality.

\section{CURRENT POLICY FRAMEWORK ON SUSTAINING ENERGY AND THE DISTRIBUTION OF ENERGY RESOURCES IN INDONESIA}

The energy policy in Indonesia is enacted in Act Number 30 of 2007 on Energy, to which the guidelines regarding policy making, provision, and energy utilisation refer. The Act of energy is aimed to change paradig $m$ of energy utilisation from supply side management to demand side management. To realise national energy security, the need for renewable energy becomes priority that balances the fossil energy that still serves as the main energy resource used in Indonesia. Moreover, exploration and exploitation of energy resource should be done as part of national energy security [13].

Indonesia still highly depends on imports of oil and other similar products. In 2015, oil import still accounted for more than $75 \%$ from its final consumption. This figure has experienced a rise compared to that in 2014. Higher dependency of oil import indicates the low national security in Indonesia. Therefore, Indonesia does not hold significant bargaining position in terms of fulfilling the need for sustainable and affordable domestic oil [14].

On the other hand, while the total of renewable energy potential (EBT) which reaches more than $400 \mathrm{GW}$, the utilisation of EBT in Indonesia is still low to date, which is less than $2 \%$ of the total of potential EBT. In addition, renewable energy production in 2015 showed negative trend, especially regarding hydropower that saw fall in production to $7.6 \%$ or equal to $3 \mathrm{MBOE}$ from $38 \mathrm{MBOE}$ to 35 MBOE. The most marked decrease was apparent in biodiesel close to $60 \%$ in 2015 from nearly 4 millions $\mathrm{KL}$ in 2014 to about 1.6 millions KL. The decreasing production in biodiesel in 2015 was affected by the falling production of crude palm oil (CPO) as affected by El Nino [14].

Through energy policy enacted in Presidential Decree Number 79 of 2014, the government tries to keep pushing and increasing the utilisation of renewable energy and to reduce utilisation of energy with fossil fuel. By 2025, the government plans to target utilisation of energy as much as 400 MTOE and by 20501000 MTOE. By 2025, crude oil accounts for $25 \%$, natural gas for $22 \%$, coal for $31 \%$, and ET for $23 \%$, while by 2050 , oil accounts for $20 \%$, natural gas for $24 \%$, coal for $25 \%$, and EBT for $31 \%$ (see diagram $1)$.

\section{DIAGRAM 1.}

The PREDICTION AND T ARGETS OF POWER Plants, ENERGY AND ELECTRICITY CONSUMPTION FROM 2016-2050[15]

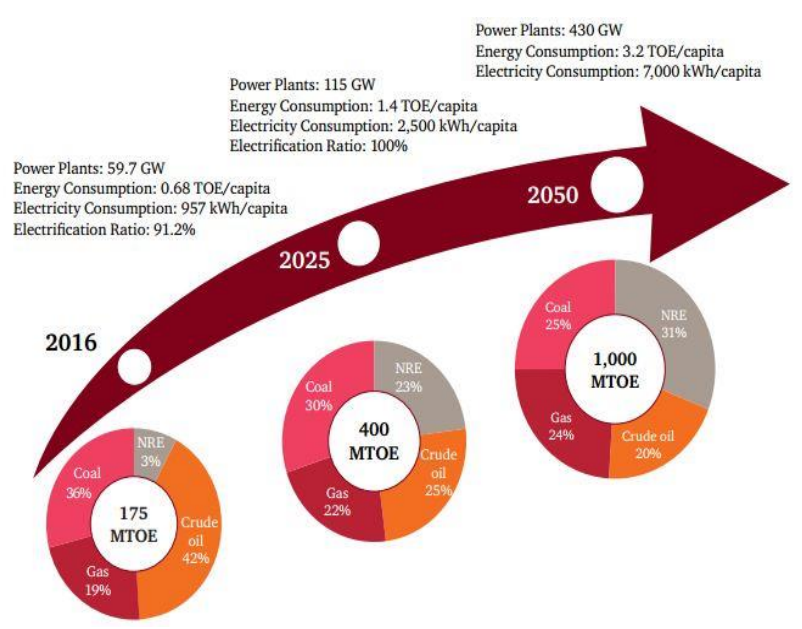

In addition to energy security, even distribution of electrical availability in regions also presents a challenge for government. In 2015, the electrification in the entire Indonesia accounted for about $88 \%$, from only $67 \%$ in 2010 . In 2019, the government predicts the availability of electricity to grow to $97 \%$ and $99.7 \%$ in 2026 . Figure 2 presents the availability of electricity in Java, reaching more than $90 \%$, but the east part of Indonesia like East Nusa Tenggara and Papua is lagged and the electrification is still below $60 \%$ [16].

FIGURE 2.

ELECTRIFCATION RATES ACROSS INDONESIA, 2015

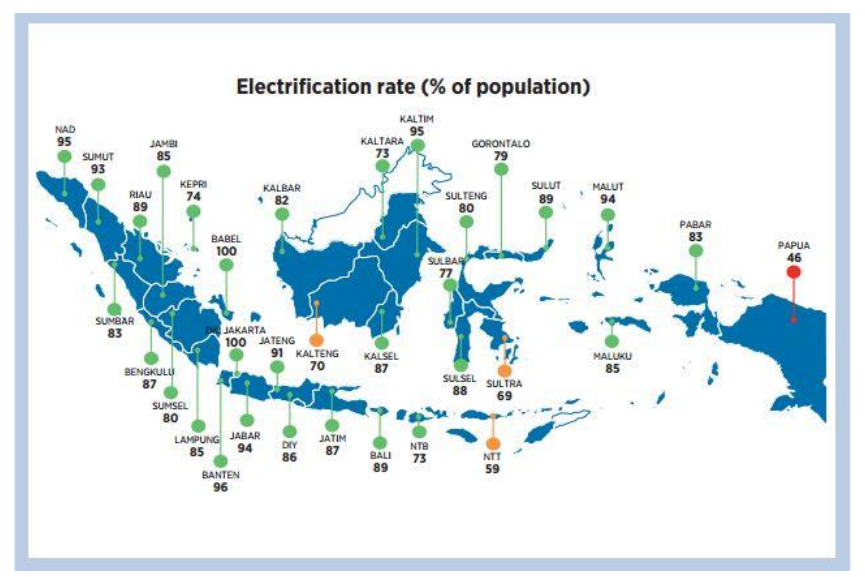

The government holds the responsibility to provide the electricity especially in remote regions through connection to the existing networks and to develop new mini network. At present time, the government focuses on developing renewable energy resource such as solar panel that is potential to provide electricity in 7000 villages (about 1.3 million households) in 2020 [16]. Moreover, the renewable energy like hydropower, bioenergy power, geothermal 
power, wind, and ocean current power should also be developed through the government policy. The government policy to provide renewable energy for 2025 is also presented in this paper.

TABLE 2.

OVERVIEW OF TARGETS, POLICIES AND REGULATION FOR RENEWABLE ENERGY IN INDONESIA [16]

\begin{tabular}{|c|c|c|c|}
\hline & $\begin{array}{l}\text { Target } \\
2025\end{array}$ & $\begin{array}{l}\text { Current policy } \\
\text { framework and } \\
\text { instruments }\end{array}$ & Regulation \\
\hline \multicolumn{4}{|c|}{ Overall Targets } \\
\hline $\begin{array}{l}\text { Renewable } \\
\text { energy in } \\
\text { TPES } \\
\text { (excluding } \\
\text { traditional } \\
\text { uses of } \\
\text { bioenergy) }\end{array}$ & $23 \%$ & & $\begin{array}{l}\text { Government } \\
\text { Regulation } \\
\text { No. 79/2014 }\end{array}$ \\
\hline $\begin{array}{l}\text { Renewable } \\
\text { energy in } \\
\text { power } \\
\text { generation }\end{array}$ & $25 \%$ & & $\begin{array}{l}\text { Draft } \\
\text { RUKN } \\
2015-2034 \\
\text { (plan, no } \\
\text { regulation) }\end{array}$ \\
\hline \multicolumn{4}{|c|}{ Power Sector Target } \\
\hline $\begin{array}{l}\text { Large } \\
\text { Hydro } \\
\text { power }\end{array}$ & $\begin{array}{l}18.3 \\
\mathrm{GW}\end{array}$ & $\begin{array}{l}\text { Regulation allows } \\
\text { for power purchase } \\
\text { through direct } \\
\text { selection or direct } \\
\text { appointment } \\
\text { without the } \\
\text { minister's approval } \\
\text { as long as the tariff } \\
\text { does not exceed the } \\
\text { levelised base cost } \\
\text { at the power plant's } \\
\text { busbar. }\end{array}$ & $\begin{array}{l}\text { MEMR No. } \\
\text { 03/2015 }\end{array}$ \\
\hline $\begin{array}{l}\text { Small } \\
\text { Hydro } \\
\text { Power }\end{array}$ & $\begin{array}{l}3.0 \\
\text { GW }\end{array}$ & $\begin{array}{l}\text { Different feed-in- } \\
\text { tariff for projects up } \\
\text { to } 250 \mathrm{~kW} \text { (low } \\
\text { voltage) and } 10 \\
\mathrm{MW} \text { (medium } \\
\text { voltage) for } 20 \\
\text { years. Rates vary } \\
\text { for y ears } 1-8 \text { and 9- } \\
20 \text {, and between } \\
\text { locations (60\% } \\
\text { premium for Papua, } \\
\text { for example). Tariff } \\
\text { range is indexed at } \\
\text { USD } 0.12 \text { - } \\
0.144 / \mathrm{kWh} \text { for the } \\
\text { frst } 8 \text { years and } \\
\text { USD } 0.075 \text { - } \\
0.09 / \mathrm{kWh} \text { for years } \\
9-20\end{array}$ & $\begin{array}{l}\text { MEMR No. } \\
19 / 2015\end{array}$ \\
\hline $\begin{array}{l}\text { Bioenergy } \\
\text { power }\end{array}$ & $\begin{array}{l}5.5 \\
\text { GW }\end{array}$ & $\begin{array}{l}\text { Feed-in tariffs in the } \\
\text { range of about USD } \\
0.108-0.272 / \mathrm{kWh} \\
\text { depending on } \\
\text { location, voltage } \\
\text { (low/medium) and } \\
\text { type of bioenergy } \\
\text { (biomass, biogas, } \\
\text { municipal solid } \\
\text { waste). } \\
\text { Acceleration of }\end{array}$ & $\begin{array}{l}\text { MEMR No. } \\
21 / 2016 \\
\text { (biomass } \\
\text { and biogas) } \\
\text { and MEMR } \\
\text { No. 44/ } \\
2015 \\
\text { (municipal } \\
\text { waste) } \\
\text { Presidential } \\
\text { Decree No. }\end{array}$ \\
\hline
\end{tabular}

\begin{tabular}{|c|c|c|c|}
\hline & & $\begin{array}{l}\text { municipal solid } \\
\text { waste power plants } \\
\text { are done for seven } \\
\text { specifc cities and } \\
\text { include, as an } \\
\text { example, ease of } \\
\text { permitting and the } \\
\text { use of government } \\
\text { funds to pay for the } \\
\text { feasibility studies. }\end{array}$ & $\begin{array}{l}\text { 18/2016 } \\
\text { (municipal } \\
\text { solid waste) }\end{array}$ \\
\hline $\begin{array}{l}\text { Geothermal } \\
\text { power }\end{array}$ & $\begin{array}{l}7.1 \\
\text { GW }\end{array}$ & $\begin{array}{l}\text { Direct geothermal } \\
\text { within conservation } \\
\text { forests only allowed } \\
\text { when used for } \\
\text { nature tourism } \\
\text { activities. For } \\
\text { indirect geothermal } \\
\text { (power) need permit } \\
\text { from Ministry of } \\
\text { Forestry if location } \\
\text { is in forest areas. } \\
\text { Tariff range of USD } \\
0.122-0.296 / \mathrm{kWh} \\
\text { dependent on year } \\
\text { of commercial } \\
\text { operation and area } \\
\text { in which project is } \\
\text { located. }\end{array}$ & $\begin{array}{l}\text { MEMR No. } \\
17 / 2014 \\
\text { Republic of } \\
\text { Indonesia } \\
\text { Law No. } \\
\text { 21/2014 }\end{array}$ \\
\hline Solar PV & $\begin{array}{c}6.4 \\
\text { GW }\end{array}$ & $\begin{array}{l}\text { Feed-in tariff for } \\
250 \mathrm{MW} \text { of } \\
\text { capacity, with } 150 \\
\text { MW in Java and the } \\
\text { remaining } 100 \mathrm{MW} \\
\text { spread over other } \\
\text { locations. Feed-in } \\
\text { tariffs range from } \\
\text { USD } 0.145 / \mathrm{kWh} \text { in } \\
\text { Java to USD } \\
0.25 / \mathrm{kWh} \text { in Papua } \\
\text { for } 20 \text { years. }\end{array}$ & $\begin{array}{l}\text { MEMR No. } \\
19 / 2016\end{array}$ \\
\hline Wind & $\begin{array}{c}1.8 \\
\text { GW }\end{array}$ & $\begin{array}{l}\text { Not covered by } \\
\text { specifc regulation at } \\
\text { the moment, } \\
\text { although a feed-in } \\
\text { tariff is under } \\
\text { discussion. Current } \\
\text { projects directly } \\
\text { negotiated with } \\
\text { PLN. }\end{array}$ & \\
\hline $\begin{array}{l}\text { Ocean } \\
\text { power }\end{array}$ & $\begin{array}{c}3.1 \\
\text { GW }\end{array}$ & $\begin{array}{l}\text { Not covered by } \\
\text { specifc regulation. }\end{array}$ & \\
\hline \multicolumn{4}{|c|}{ Ethanol blending } \\
\hline $\begin{array}{l}\text { Transportati } \\
\text { on }\end{array}$ & $20 \%$ & $\begin{array}{l}2 \% \text { blending } \\
\text { mandate in } \\
\text { transportation } \\
\text { (PSO), } 5 \% \text { in non- } \\
\text { PSO transportation } \\
\text { for } 2016 .\end{array}$ & $\begin{array}{l}\text { MEMR No. } \\
12 / 2015\end{array}$ \\
\hline Industry & $20 \%$ & $\begin{array}{l}5 \% \text { blending } \\
\text { mandate for } 2016\end{array}$ & $\begin{array}{l}\text { MEMR No. } \\
12 / 2015\end{array}$ \\
\hline \multicolumn{4}{|c|}{ Biodiesel Blending } \\
\hline $\begin{array}{l}\text { Transportati } \\
\text { on }\end{array}$ & $30 \%$ & $\begin{array}{l}20 \% \text { blending } \\
\text { mandate for } 2016\end{array}$ & $\begin{array}{l}\text { MEMR No. } \\
12 / 2015\end{array}$ \\
\hline Industry & $30 \%$ & $\begin{array}{l}20 \% \text { blending } \\
\text { mandate for } 2016\end{array}$ & $\begin{array}{l}\text { MEMR No. } \\
12 / 2015\end{array}$ \\
\hline Electricity & $30 \%$ & $\begin{array}{l}30 \% \text { blending } \\
\text { mandate for } 2016\end{array}$ & $\begin{array}{l}\text { MEMR No. } \\
12 / 2015\end{array}$ \\
\hline Aviation & $3 \%$ & Alternative biofuel & MEMR No. \\
\hline
\end{tabular}




\begin{tabular}{|l|l|l|l|}
\hline blending & $(2020)$ & $\begin{array}{l}\text { for aircraft, 2\% } \\
\text { blending mandate } \\
\text { for 2018 }\end{array}$ & $12 / 2015$ \\
\hline
\end{tabular}

Overall, measures taken by central and regional governments regarding the implementation of strategy of development and utilisation of national energy resource are as follows [15]:

a. Utilisation of renewable energy from waterflow and waterfall, geothermal, sea wave, tidal and ocean thermal energy conversion and wind for electricity generation;

b. Utilisation of solar for electricity generation and nonelectricity energy for industry, households and transportation:

c. Utilisation of biomass and waste for electricity generation and transportation;

d. Utilisation of natural gas for industry, electricity generation, households and transportation, specifcally in cases that offer the highest value added;

e. Utilisation of coal for electricity generation and industry;

f. Utilisation of new solid and gas energy sources for electricity generation;

g. Utilisation of ocean thermal energy conversion as a prototype for early-stage connection to the power grid;

h. Utilisation of PV solar cells for transportation, industry, commercial buildings and households; and

i. Maximising and making compulsory the utilisation of solar components and solar power plants that are manufactured domestically

\section{CHALLENGES AND OPPORTUNITIES OF SUSTAINING ENERGY USING VIRTUAL POWER PLANT}

Procurement, utilisation, and even distribution of energy are essential aspects to run the economy in the entire Indonesia. In 2016, final energy consumption reached 751.3 millions BOE, with the following consumption composition: a) fuel oil accounted for $41.7 \%$; (b) electricity for $19.0 \%$ (c) crude oil for $14.6 \%$; (d) coal for $9.1 \%$; (e) LPG for $8.1 \%$; and the remaining is non-energy use. The consumption of electricity is projected to keep increasing annually to about $6 \%$ [17].

In the distribution, communities living in villages have not received electrical currents. Therefore, to increase the ratio of electrification and even distribution of energy, the government has launched program aimed to distribute electricity to 2500 villages. It means that the government should be committed to encouraging the development of power plant from renewable energy through several incentive policies without having to worry about increasing electricity bill that has become a burden for the consumers [17]. Therefore, domestic industries need to be pushed to supply the components of technology, such as VPP distributed to remote regions for more evenly distributed development without overlooking the opportunities and challenges encountered in the use of VPP at national level.

\section{A. Challenges of sustaining energy using virtual power plant}

Indonesia is a state where the electricity is not evenly distributed. To date, several regions in Indonesia have not received electrical currents. In some remote areas, electrical currents are unstable and blackout can occur without warning [18].

By 2030, the capacity of energy plant in Indonesia is projected to reach $199.3 \mathrm{GW}$. For the renewable energy capacity, the government has planned for $107 \mathrm{GW}$ of energy by 2030 . At present time, the government is executing project of 35,000 watts of electricity [19]. In the future, it is expected that the electricity consumption will increase by half in addition to the massively growing urbanisation, new and modern cities, and the utilisation of digital technology. Therefore, the infrastructure used to distribute the electricity must be excellent, robust, and flexible. Demand for electrical power must be fulfilled with stable transmission but with sustainable and eco-friendly energy. To realise the possibility, the utilisation of VPP becomes crucial despite the following impeding factors in the utilisation of VPP in Indonesia [20]:

(a) The policy of energy management that is not technology-based.

Virtual Power Plant is new in energy management in Indonesia. There has not been any regulation that regulates the policy and technical structure regarding the utilisation of VPP in the distribution of renewable energy.

(b) Unavailability of infrastructure supporting VPP

Since VPP is relatively new in Indonesia, the infrastructure of Information and Communication Technology (ICT) in relation to the utilisation of VPP is not available in the country. Moreover, software to estimate the electrical power is needed to operate and distribute the VPP. With complex infrastructure, the utilisation of VPP can be costly.

(c) Participation of societies in electricity procurement

Social participation is the key factor in the success of the utilisation of VPP. At the moment, companies involved in the development of small-scale electrical networks are still not able to actively participate in the market, as the procurement is mostly dominated by the state.

(d) Cyber security threat

Technology can be in its vulnerable position regarding cyber security threat. Due to the digitalisation and network connection all over Indonesia, the government should have extra security in case of internal and external technological threat.

\section{B. Opportunities of Sustaining Energy Using Virtual Power Plant}

The opportunity given for the development of sustainable energy management through VPP in Indonesia is considerable. The implementation of current energy efficiency policy applied effectively is expected to reduce $2 \%$ of energy consumption by 2025 . Enforcing the existing 
policy and policy plan that has not been executed is predicted to reduce as much as $4.5 \%$ of energy utilisation compared to the scenario with no change in policy [21]. However, there are other ways to significantly cut energy use that can be done with VPP. Some opportunities of Indonesia to use VPP are elaborated as follows:

1. The change in electrical energy consumption

Technology transformation also alters the behaviour of electrical energy consumption in the future. Every consumer certainly wishes to figure out the electrical consumption metre accurately and transparently, to have access to controlling the electricity consumption, and surely to use the electricity efficiently. People expect to be involved as prosumers (proactive consumers) who not only use the electrical power, but also produce electrical power. The investment through VPP is beneficial when it is executed early by power dis tributors.

2. Increasing renewable energy need

The project of 35,000 megawatts power planned by the government should involve more renewable energy to prevent from contributing carbon gas that could trigger global warming and environmental damage. Fossil fuel such as coal is getting rare in addition to the fact that it gives negative impacts to environment. Therefore, the infrastructure of electrical trans mission by using VPP is quite adaptive to renewable energy resources such as solar panel or microgrid system.

\section{Better environmental awareness}

In the future, people are getting more aware of the essence of the utilisation of eco-friendly energy resources. Transmission system and network are no longer traditional (power generator to consumers). Traditional cost-revenue business model that exists is no longer relevant in the future as the consumers are also able to produce energy.

4. More complex market

The consumers will be able to produce their energy through microgrid by using solar panel and windmill. The bottom line is that the energy distribution is not on one direction from central power generator to consumers. More modern and smarter infrastructure is needed. Smart grid consists of interconnected components, in which data referred to as problem analysis can be obtained quickly. Before the crisis takes place, issue is detected to allow anticipation.

\section{Increasing interest of developed countries in VPP}

Based on the latest research report from Pike Research, there is a surge of interest in the mechanism of VPP for demand response (DR). It has changed the market landscape of VPP entirely and encouraged the considerable growth in economic sector. The capacity of VPP rose to $65 \%$ in 2011 and 2017, from 55.6 gigawatts (GW) to $91.7 \mathrm{GW}$ all over the world during the period. The transaction value of VPP also increased and hit 5.3 billion dollars in annual revenue in 2017 [22]. When the
VPP system is applicable in Indonesia, the capacity of energy will rise and the distribution will be more even.

\section{CONCLUSION}

Energy is the main need in the national economic development. Nowadays, the Indonesian government is focused on developing renewable energy for higher energy capacity and even distribution of energy. The utilisation of technology by means of VPP serves as an essential alternative to evenly distribute electrical power to remote regions in entire Indonesia. However, since the VPP is a new technology, there are of course challenges and opportunities. The challenges are (a) policy of energy management that is not technology-based (b) unavailability of supporting infrastructure for VPP; (c) participation of societies in the procurement of electricity; and (4) cyber security threat, while the opportunities of the implementation of VPP involves: (a) Change in the behaviour of electrical energy consumption; (b) the increase in renewable energy; (c) better awareness of environment; (d) more complex market; and (e) increasing interests of developed countries in VPP.

\section{REFERENCES}

[1] Engr. Mansoor-ul-Hassan, "Power Generation Methods, Techniques and Economical Strategy," Int. Tech. Sci. J., vol. 11, no. 1, p. 43, 2014.

[2] Asian Development Bank, Achieving Universal Electricity Access in Indonesia. Manila: Asian Development Bank, 2016.

[3] Agus Sugiyono, "Permasalahan dan Kebijakan Energi Saat Ini," in Seminar with BPPT dan BKK-PII, 2014, p.9.

[4] Nirarta Samadhi and A. Pradana, "Indonesia dan Krisis Energi Akut." [Online]. Available: https://wriindonesia.org/id/blog/indonesia-dan-krisis-en er gi-akut.

[Accessed: 13-Aug-2018]

[5] Y. M. P. Putra, "Peneliti Sebut Energi Fosil Hab is 2050," 2016. [Online]. Available: https://www.republika.co.id/berita/nasional/umum/16/02/16/ o2ndw3284-peneliti-sebut-energi-fosil-habis-2050.

[Accessed: 10-Aug-2018].

[6] S. K. Venkatachary, J. Prasad, and R. Samikannu, "Challenges, Opportunities and Proftability in Virtual Power Plant Business Models in Sub Saharan Africa - Botswana," Int. J. Energy Econ. Policy, vol. 7, no. 4, p. 48, 2017.

[7] P. Legros and A. F. Newman, "Contracts, ownership, and industrial organization: Past and future," J. Law, Econ. Organ., vol. 30, no. SUPPL. 1, pp. 82-117, 2014.

[8] R. Martin, "Revenue from Virtual Power Plants Will Reach \$5.3 Billion by 2017, Forecasts Pike Research," 2012. [Online]. Available: https://www.businesswire.com/news/home/20120418005337 /en/Revenue-Virtual-Power-Plants-Reach-5.3-Billion. [Accessed: 03-Aug-2018].

[9] A. Y. Abdelaziz, Y. G. Hegazy, W. El-Khattam, and M. M. Othman, "Virtual Power Plant: The Future of Power Delivery Systems," in European Workshop on Renewable Energy Systems, pp. 1-2.

[10] S. K. Venkatachary, J. Prasad, and R. Samikannu, "Barriers to Implementation of Smart Grids and Virtual Power Plant in Sub-Saharan Region-Focus Botswana," Energy Reports, vol. 4, p. 123, 2018.

[11] M. M. Othman, Y. G. Hegazy, and A. Y. Abdelaziz, "A Review of Virtual Power Plant Definitions, Components, Framework and Optimization," Int. Electr. Eng. J., vol. 6, 
no. 9, p. 2011, 2015.

[12] Z. Ma, J. D. Billanes, and B. N. Jørgensen, "Aggregation Potentials for Buildings-Business Models of Demand Response and Virtual Power Plants," Energies, vol. 10, no. 1646, p. 4, 2017.

[13] M. of E. and M. Resources, "Study of Provision and Utilisation of Oil and Gas, Coal, EBT, and Electricity," Jakarta, 2017.

[14] M. of E. and M. Resources, "Chain Management of Provision and Utilisation of National Energy," Jakarta, 2016.

[15] Y. Kamarudin, T. Boothman, and Et.al., Power in Indonesia: Investment and Taxation Guide. Indonesia: Pwc, 2017.

[16] IRENA, "Renewable Energy Prospect: Indonesia, a REmap Analysis,"Abu Dhabi, 2017.

[17] Ministry of Energy and Mineral Resources, "Kajian Penyediaan dan Pemanfaatan Migas, Batubara, EBT dan Listrik," Jakarta, 2017.

[18] D. Purwanto, "Tantangan Rumit dalam Distribusi Energi di Indonesia." [Online]. Available: https://www.kompasiana.com/dudunhamdalah/583f651f7893 73ae038b4569/tantangan-rumit-dal am-distribusi-energi-diindonesia. [Accessed: 15-Jul-2018].

[19] Angga Bratadharma, "Kapasitas Energi Terbarukan Global Naik 8,3\% di 2017.” [Online]. Available: http://news.metrot vnews.com/read/2018/04/07/856642/kapas itas-energi-terbarukan-global-naik-8-3-di-2017. [Accessed: 25-Jul-2018].

[20] Schneider Electric, "Ini 8 Alasan Mengapa Transformasi Harus Dilakukan dalam Distribusi Energi Listrik.” [Online]. Available: http://ms.kompas.com/schneider/read/12/ini-8alasan-men gapa-transformasi-harus-dilakuk an-dalamdistribusi-energi-listrik. [Accessed: 05-Aug-2018].

[21] International Energy Agency, "Energy Eficiency 2017," 2017.

[22] Colo Boulder, "Revenue from Virtual Power Plants Will Reach \$5.3 Billion by 2017, , Forecasts Pike Research," 2012. [Online]. Available: https://www.businesswire.com/news/home/20120418005337 /en/Revenue- Virtual-Power-Plants-Reach-5.3-Billion.

[Accessed: 13-Aug-2018]. 